\title{
FACTORS THAT SHAPE BUSINESS MODEL: IDENTIFICATION WITH THE USE OF A STRUCTURED INTERVIEW
}

\author{
Konrad KRAJEWSKI \\ Wroclaw University of Science and Technology, Faculty of Computer Science and Management, Doctoral \\ School; konrad.krajewski@pwr.edu.pl, ORCID: 0000-0001-7518-4228
}

Purpose: This paper is to present an in-depth interview as a tool for identifying factors conducive to changing a business model in start-ups. The first part of the paper deals with the issues related to defining a business model, examples of its components, as well as drivers of change. The second part of the paper presents the advantages of qualitative research in studying the problems involved in a business model and includes the author's proposal for an original structured interview form aimed at identifying drivers of change in the business model.

Design/methodology/approach: These topics are discussed based on the literature review.

Findings: A properly constructed structured interview appears to be an effective tool to collect qualitative data on the factors influencing the business model change from the management level, because the people who make decisions in an organization are the best source of information on strategy and business model.

Originality/value: This paper proposes a research tool which is a structured interview consisting of 5 sections, sample questions for each section are presented to identify the factors affecting the change of business model.

Keywords: management, business model, start-up, Business Model Canvas, structured interview.

\section{Introduction}

In the $21^{\text {st }}$ century, technological progress and globalisation have fuelled a rash of young enterprises which, with the help of innovative solutions, technologies, or business models can effectively compete with mature international corporations. An additional stimulant to entrepreneurship is access to private and public funds. Along with the development of new technologies, numerous venture capital funds and sectoral grant programmes have been created to support entrepreneurship and diversify the risk for entrepreneurs and private investors alike. 
Young entities that operate based on innovative solutions are known as start-ups. Eric Ries defines them as organisations the main goal of which is to get an insight into the market, customer needs, and the best method to commercialise a specific idea "under conditions of extreme uncertainty" (Ries, 2012). To earn money effectively in such conditions, business entities have to analyse market-derived information on an ongoing basis, assess the effectiveness of their business model, and, ultimately, introduce relevant changes to it. This process is key for start-ups that only dispose of limited capital from external sources (for example from business angels, venture capital funds, or grant-distributing institutions and state organisations). Given the multitude of factors that influence the shape of a business model, it is essential to identify them early enough so as to introduce relevant changes to the existing model in a timely manner. Unfortunately, entrepreneurs who manage start-ups are rarely conversant with the rudiments of management, even if they do possess professional know-how. For this reason, it is extremely important to assist them in the process of identifying such drivers of change. To this end, field research should be carried out among start-up founders, mentors, and members of their advisory or supervisory boards. This paper aims at presenting an in-depth interview as a tool for identifying factors that shape a business model in start-ups.

The first part of the study presents definitions of the business model and its shaping factors that can be found in the literature on the subject. The second part contains justification for choosing a structured interview as a tool for identifying factors shaping the business model, as well as the author's original proposal for an interview form. The study ends with a summary and conclusions.

\section{Definition of business model}

To this date, a definition of the business model (BM) has not been standardised or specified in the literature on the subject. Empirical research proves that the beginnings of the business model as such can be traced back to the intensive development experienced by the IT industry at the turn of the $20^{\text {th }}$ and $21^{\text {st }}$ centuries. The growing IT industry did not limit itself to offering new solutions, products, and tools to improve the life of society and entrepreneurs alike, but also generated profits from subscription arrangements or success-based settlements with the success measured by an increase in revenues or customer base or by a reduction in costs, time or energy. In 1998, Timmers proposed a definition of business model, describing it as "an architecture for the product, service and information flows, including a description of the various business actors and their roles; and a description of the potential benefits for the various business actors; and a description of the sources of revenues" (Timmers, 1998, p. 4). There is no doubt that this is an accurate way to describe the BM; however, over the years, it has evolved into more general and universal definitions, such as: "the company idea for earning money" 
(Koźmiński, 2004, p. 123), "a blueprint for a strategy to be implemented through organisational structures, processes, and systems" (Osterwalder and Pigneur, 2013, p. 19). Increased interest of scientists in the subject of business model has resulted in the emergence of research focused on identifying factors that influence the BM. At the same time, tools have appeared on the market that enables entrepreneurs to effectively define, specify and implement a business model in their respective organisations. The most widespread and universal tool is the Business Model Canvas, developed by Alexander Osterwalder and Yves Pigneur. It is used to create a core corporate strategy and define a value proposition for a specific customer group.

Canvas (Osterwalder and Pigneur, 2013, p. 19) is a template consisting of nine building blocks describing the elements that define the process of and logic behind making money. The proposal of such a universal tool is all the more important that for young enterprises the $\mathrm{BM}$ is the basis for creating strategies. It is a kind of foundation for an organisation and, if properly constructed, it will enable the development of an effective and efficient strategy once the organisation becomes a mature enterprise.

The BM Canvas template is a universal tool that can be used across many industries, ranging from IT, e-commerce, agriculture, power industry, and transport, to a pharmacy, diagnostics, biotechnology, or veterinary medicine. Its additional advantage is the simplicity of implementation, which allows the project, idea, need, or technology to be validated at the seed stage of their development by people who have no business experience or management expertise whatsoever. To identify the BM for their project, idea, or organisation, the entrepreneur must answer specific questions about each of the nine components of the canvas that focus on four business areas: offering, customer, infrastructure, and financial viability. The approach by Osterwalder and Pigneur assumes the presence of 9 elements that make up a business model, namely (cf. Fig. 1): value propositions, customer segments, channels, customer relationships, potential and resources, activities, partners, revenues, and costs.

\begin{tabular}{|c|c|c|c|c|}
\hline Key partners & Key activities & $\begin{array}{c}\text { Value } \\
\text { propositions }\end{array}$ & $\begin{array}{c}\text { Customers } \\
\text { relationships }\end{array}$ & $\begin{array}{c}\text { Customer } \\
\text { segments }\end{array}$ \\
& Key resources & & Channels & \\
& & & \multicolumn{2}{|c|}{ Revenue streams } \\
\hline \multicolumn{2}{|c|}{ Cost structure } & & \\
\hline
\end{tabular}

Figure 1. Business Model Canvas: nine business model building blocks. Source: Osterwalder, Pigneur, et al. 2010. 
Another example of the components of a business model is a concept by Gassmann et al. (2014), which distinguishes the following dimensions:

- the "Who" - defining the customer, the target audience of the offering - this is the core of the concept;

- the "What" - defining the customer value proposition;

- the "How" - defining the processes and activities, as well as the resources and skills necessary to create and deliver the offering to the customer;

- the "Value" - answering the questions: What costs does a given activity generate? How is revenue created? How is the value proposition created?

The customer value proposition is also the basis for the concept by Mark W. Johnson, Clayton M. Christensen, and Henning Kagermann (2010) who came up with four interlocking elements making a business model, namely:

- building block 1 - customer value proposition;

- building block 2 - profit formula;

- building block 3 - key resources required to deliver the value proposition to the targeted customer;

- building block 4 - key processes, including rules, metrics, and norms that allow a profitable delivery of the customer value proposition.

It must be noted that only the most popular components of the business model have been invoked here and that all of them undoubtedly share a customer-centric approach.

\section{Factors shaping business model in start-ups}

A start-up organisation, due to its flat structure and early stage of development, learns intensively, collects data, and analyses information from the macro- and micro-environment to define its effective and efficient BM. Along with the development of the organisation and expansion of its organisational structures and procedures, the existing business model evolves to take the form of a strategy. Therefore, for the company's effectiveness, it is essential to define an appropriate BM as early as possible. An imprecise or incorrect business model will translate into ineffective or mistaken decisions taken based on underestimated or erroneous data. Such a BM will eventually turn into an ineffective corporate strategy, which, at best, will increase the organisation's costs while decreasing its revenues. In a pessimistic scenario, an ineffective strategy may bring losses or even force the company to close down.

As start-ups are faced with the changing environment and mature competition, they must be innovative in all areas of their activity, going beyond the business model. Indeed, a young organisation is subject to numerous influences coming from its macro- and micro-environment. 
Exogenous (external) factors are economic, formal and legal, market, technological, competence-related, social, political, and competitive factors.

On the other hand, among endogenous (internal) factors we can mention:

- tangible resources (plant and equipment, capital, company assets, location);

- intangible resources (knowledge and creativity of the staff, brand, credibility, organisational culture);

- management efficiency (ability to progress);

- business arrangements and links (sources of income, relationships);

- competitiveness of products and services (creating innovative solutions, increasing key competencies);

- activities and processes within the company.

The topic of factors shaping the business model is brought up by the authors quoted above, namely Alexander Osterwalder and Yves Pigneur (2013, pp. 204-213). They have identified exogenous factors that influence the business model in terms of four areas: key trends, market forces, macroeconomic forces, and industry forces ( $c f$. Fig. 2). The authors have identified these factors based on the example of the pharmaceutical industry.

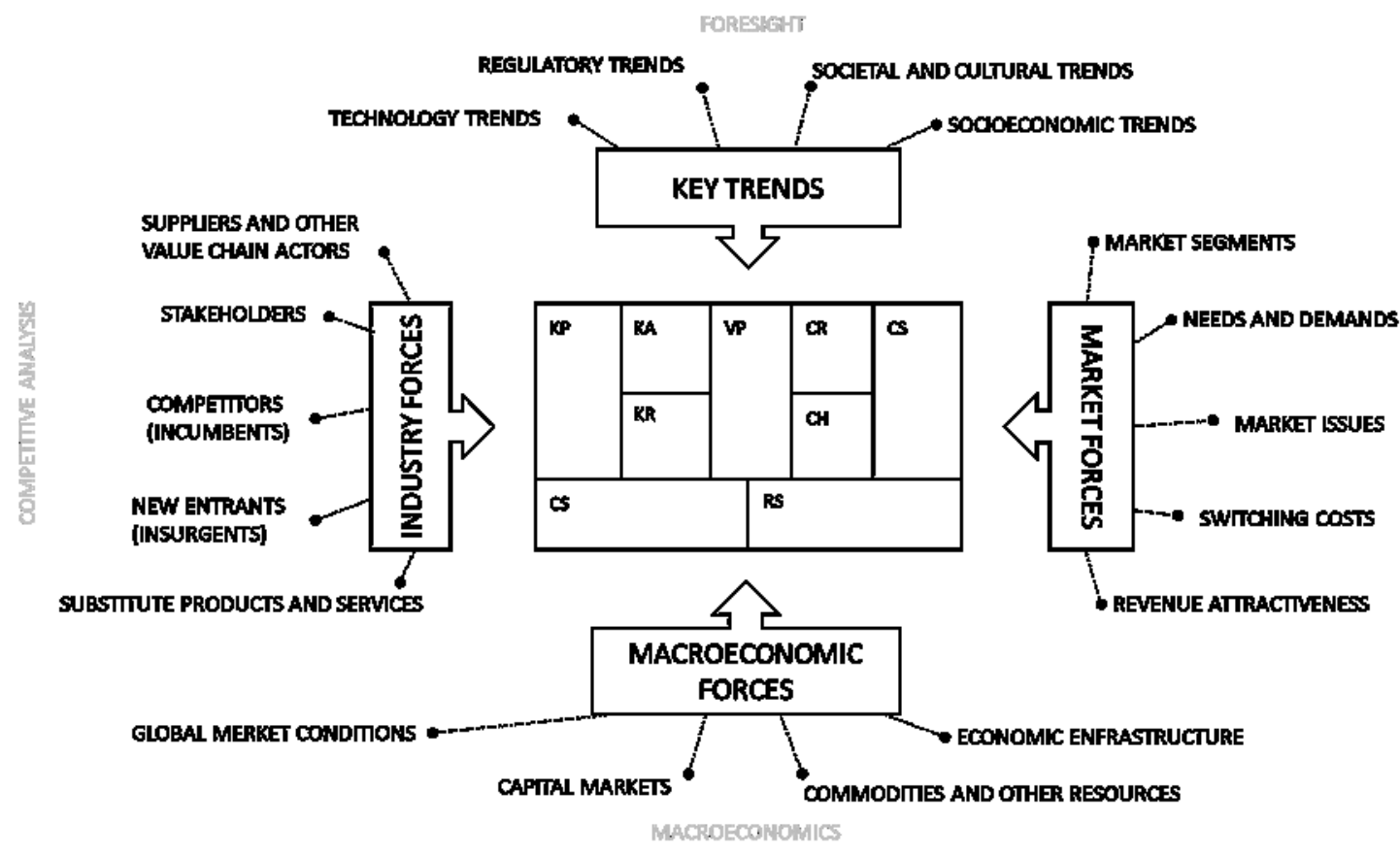

Figure 2. Exogenous factors influencing the shape of business model according to Osterwalder and Pigneur. Adapted from: „Tworzenie modeli biznesowych. Podręcznik wizjonera” by A. Osterwalder, Y. Pigneur. Copyright 2013 by Wydawnictwo Helion, Gliwice p. 205.

It turns out that in the literature on the subject we find numerous works that focus on factors shaping business model, and the factors themselves are often repeated across individual papers. When analysing the available publications, several basic factors that are drivers of change for a business model can be distinguished, such as: products and services (Afuah and Tucci, 2003; Linder and Cantrell, 2004), customer value proposition (Betz, 2002; Magretta, 2002; 
Mahadevan, 2000), target customers (Chesbrough and Rosenbloom, 2002; Slawotzky et al., 1997), structure of the value chain/position of the company in the value chain (Mahadevan, 2000; Timmers, 1998), relationships with partners (Timmers, 1998), strategy and its elements (Chesbrough and Rosenbloom, 2002), resources and competences (Linder and Cantrell, 2004) and revenue sources (Afuah and Tucci, 2003).

Considering the factors listed above coupled with limited financial resources and access to information, the fact remains that start-ups are high-risk ventures. Nevertheless, they also have some specific advantages, such as the ability to make quick decisions (in the IT industry, decision-making processes take weeks, and in the biotech industry-years), continuous learning through experiments, and, last but least, the ability to freely exploit and analyse information from the international market, ecosystem and customers. To achieve and maintain long-term competitiveness in a start-up, interdisciplinary competences and skills from founders, advisors, mentors, investors, and members of supervisory and advisory boards are a must. It is a unique configuration of skills and experience from many industries that lets a start-up develop steadily. By acquiring and analysing market data it can implement quick and effective changes in its goals, strategies, and business model itself, updating them accordingly.

\section{Business model research methods}

Business models as a concept are analysed by social sciences as part of qualitative research. Therefore, it is necessary to resort to methods that will bring possibly the most reliable information. Such methods include field research, the key advantage of which is a comprehensive perspective they offer to the researcher. Indeed, the first-hand contact with the analysed social phenomenon is a prerequisite for its deeper and more comprehensive understanding. Additionally, the researcher has an opportunity to delve into nuances in the attitudes and behaviours of the respondents, which are typically overlooked by those employing other methods (Babbie, 2004, pp. 309-310).

Among qualitative methods, an excellent technique for studying business models, including their drivers of change, are structured and semi-structured interviews. They are a frequent choice among researchers, which only testifies to their effectiveness. An example of their practical use is the study by Francesca Capo and her team comprising 41 semi-structured interviews to analyse four Italian companies located within the pharmaceutical district (Capo et al., 2014). The added value of their work is the extension of analyses with quantitative data obtained from secondary sources of the companies participating in the study.

Another example of qualitative research on business models is the work of Slávik and Hanák (2017), who interviewed a group of 30 service companies. Their research was to explain the relationship between business model and business strategy. 
Andrej Jerman et al. (2019), in turn, asked the following questions in their structured interviews: What obstacles do you see in your company for a transition from a traditional to the digital business model? What are the benefits of a new, digital business model? Which are critical factors that influence transitions from a traditional to a digital business model?

Summing up, a structured interview seems to be the best method to identify factors that are a driving force for changing a business model. In this context, interviews with start-up founders (CEOs), mentors, members of advisory or supervisory boards in organisations should be conducted. Decision-makers are the best source of information for identifying the motives, reasons, and drivers for change and, most importantly, for assessing the effectiveness of the change made to the BM.

\section{A structured interview proposal to identify a change in the business model}

The structured interview scenario has been created based on the literature on the subject, empirical research, as well as the knowledge and experience of entrepreneurs from two startups operating on the markets of diagnostics and veterinary science. The scenario is divided into 5 sections:

1. Introduction to the topic.

2. Description of the organisation.

3. Description of the technology/product/service.

4. Description of the business model.

5. Impact of the market environment on the business model.

Each section has a specific purpose and duration. A single interview should last 75 minutes, but can be extended to 90 minutes.

The first section is to explain the purpose of the study, its duration, confidentiality, rules of discussion, and basic concepts while emphasizing that there are no right or wrong answers. In the introduction, it should be assumed that the respondent has little or no knowledge of business models, and thus a brief explanation is needed. Start-up founders often have an industry-specific education related to service, technology, or product offered by a start-up. For example, founders of biotech companies will typically be pharmacists, laboratory diagnosticians, or biotechnologists.

The second section of the interview has been constructed in such a way as to obtain basic information about the organisation, including the year of establishment, the number of employees, details of the founders, background, sources, and rounds of financing, experience of the founders, advisors or partners. The information obtained in this section provides an overview of the organisation, its human resources, and knowledge capacities to which it has 
direct access. A sample question in section two can be as follows: Does your organisational structure include investors, an advisory board, or an active supervisory board (what does your ownership structure look like in short)? If yes, do they back up the activities of the organisation with their knowledge?

In the third part of the interview, the respondent provides information on the product/technology offered or developed against the market and competition. With the knowledge gained in this section, it will be possible to determine what problem is solved by the technology or product in question and what the innovative potential and the technology TRL are based on (if it has not been implemented on the market yet). A sample question in this part of the interview can be: Why would customers opt for your product/service rather than your competitors' solution?

The most important part of the structured interview to which the most time is devoted is part four: "Description of the business model". The section focuses on the identification of the organisation's business model, its most important elements according to the respondent, endogenous factors affecting the BM, and changes that have occurred within the business model since the organisation's start date. Based on the information thus obtained, an attempt can be made to establish the determinants of effectiveness whenever changes are introduced to the business model to achieve the company's goals. What is more, the question can be answered whether the organisation monitors and manages its business model at all. Examples of questions in this part of the interview are: Were the changes to your business model usually: adaptive (meant to adapt to the rules prevailing in the industry) or innovative (meant to introduce innovative solutions)? Does the organisation solicit feedback from customers or other stakeholders to change its BM? Are you able to say how many times your business model has been changed over 3 years? In your opinion, were the changes radical in nature? Why was the BM changed?

The international economic and social situation is constantly changing due to the global pandemic, throwing many industries, such as HoReCa and aviation into turmoil or even causing market collapses. Therefore, it is also necessary to identify specific exogenous factors influencing the BM, although the literature already defines external factors that have a direct and indirect impact on organisations. The interviewer should also pay attention to and try to obtain information on how the macro-and microenvironment influences the process of changing the business model given the global situation these days. The purpose of the fifth section of the interview is to identify the external factors that exert the greatest impact on changes in the BM and to determine whether the pandemic has had a positive or negative impact on the organisation and its business model. Examples of questions in this part of the interview are as follows: Has the epidemiological situation affected your company? If yes, how? Has the epidemiological situation affected or is affecting your business model? 
It is a matter of key importance that a structured interview guides the respondents towards honest answers. The participants should delve into the details of their organisations and business models and provide a sincere reflection of situations or factors that were the rationale for changes in the BM. It should be re-emphasized that start-up founders typically have knowledge and experience in the field of exact and natural sciences, whereas social sciences are often alien to them or, at best, something that they are just getting acquainted with. Therefore, the interview process must subtly help the respondents understand the purpose of the study while guiding them towards the identification of changes that take place in their BMs. The interviewer should not make the respondents aware, directly or indirectly, that they lack knowledge of their business model, as this may discourage honesty and/or make the respondents reluctant to own up to their mistakes.

At the stage of collecting qualitative data from the executive, the interview questionnaire seems to be a perfect choice as we obtain information and data directly from the right source, bypassing lower-level employees whose knowledge may be fragmentary. On the other hand, the challenge for this type of research is the access to potential respondents and the involvement of the subjects thus recruited in the research process.

\section{Summary}

The business model is a concept widely analysed in the literature on the subject, starting from the problems related to its definition, through typology, up to change drivers. Building a business model in start-ups, which are highly innovative young entities at an early stage of development, but exposed to a considerable risk of bankruptcy at the seed stage of their organisation, is a topic that deserves attention. If a business model is defined at an early stage of the company's development, the number of mistakes in managing its operations can be limited and key management decisions - streamlined. In this context, there is no doubt that identification of drivers for changing the existing business model is necessary to timely revise any inoperative arrangements. Structured interviews allow such identification due to their qualitative nature. They offer an opportunity for a comprehensive and subjective insight into the analyzed phenomenon from the perspective of those involved in the process. The form proposed here is dedicated to start-up founders, mentors, members of the supervisory board, etc., i.e. the key people in the structure of the organisation. This research tool will be the basis for future research on business model changes. It should be remembered, however, that the results of any research based on structured interviews cannot be generalised for the population due to their subjective nature and purposeful sampling, which significantly reduces the inference process. The research tool in the form of a structured interview will be the basis for future research on identifying the factors shaping business models in enterprises. 


\section{References}

1. Afuah, A., and Tucci, Ch.L. (2003). Biznes internetowy - strategie i modele. Kraków: Oficyna Ekonomiczna.

2. Babbie, E. (2004). Badania społeczne w praktyce. Warszawa: PWN.

3. Betz, F. (2002). Strategic Business Models. Engineering Management Journal, Vol. 1, Iss. 14, pp. 21-27.

4. Capo, F., Brunetta, F., and Boccardelli, P. (2014). Innovative business models in the pharmaceutical industry: A case on exploiting value networks to stay competitive. International Journal of Engineering Business Management, Vol. 6.

5. Chandler, A.D. (1962). Strategy and Structure. Cambridge: MIT Press.

6. Chesbrough, H., and Rosenbloom, R.S. (2002). The role of the business model in capturing value from innovation: evidence from XEROX Corporation's technology spin-off companies, Industrial and Corporate Change, Vol. 11, Iss. 3, pp. 529-555.

7. Gassmann, O., Frankenberger, K., and Csik, M. (2014). Revolutionizing the Business Model. In: Management of the Fuzzy Front End of Innovation (pp. 89-97). Springer International Publishing.

8. Jerman, A., Erenda, I., and Bertoncelj, A. (2019). The influence of critical factors on business model at a Smart Factory: a case study. Business Systems Research, Vol. 10, Iss. 1, pp. 42-52.

9. Johnson, M.W., Christensen, C.M., and Kagerman, H. (2010). Reiventing your Business Model. Harvard Business Review on Business Model Innovation, pp. 47-70.

10. Klincewicz, K. (2016). Zarzadzanie, organizacje i organizowanie przeglad perspektyw teoretycznych, In: M. Karda (Ed.), Pojęcia i typy modeli biznesu (pp. 307-315). Warszawa: Wydawnictwo Naukowe Wydziału Zarządzania Uniwersytetu Warszawskiego.

11. Koźmiński, A.K. (2004). Zarządzanie w warunkach niepewności. Warszawa: PWN.

12. Linder, J.C., and Cantrell, S. (2004). Changing Business Models: Surveying the Landscape. Accenture Institute for Strategic Change, p. 2004.

13. Magretta, J. (2002). Why business models matter? Harvard Business Review, Vol. 80, Iss. 5, pp. 86-92.

14. Mahadevan, B. (2000). Business Models for Internet-based E-Commerce: An Anatomy, California Management Review, Vol. 42, Iss. 4, pp. 55-69.

15. Osterwalder, A., Pigneur, Y. (2013). Tworzenie modeli biznesowych. Podręcznik wizjonera. Gliwice: Wydawnictwo Helion.

16. Ries E. (2011). The Lean Startup: How Constant Innovation Creates Radically Successful Businesses. London: Penguin Group. 
17. Rissanen, T., Ermolaeva, L., Torkkeli, L., Ahi, A., Saarenketo, S. 92020). The role of home market context in business model change in internationalizing SMEs. European Business Review.

18. Romanowska, M. (2016). Determinanty innowacyjności polskich przedsiębiorstw. Przegląd Organizacji, Vol. 2, Iss. 913, pp. 29-35.

19. Slavik, S., and Hanak, R. (2017). Identification of relation between business model and business strategy and measurement of its tightness. Problems of Management in the 21th Century, Vol. 12, Iss. 1, pp. 54-68.

20. Slywotzky, A.J., Morrison, D.J., and Andelman, R. (1997). The Profit Zone-How Strategic Business Design Will Lead You to Tomorrow's Profits. New York: Random House.

21. Thompson, A.A., and Strickland, A.J. (1996). Strategic management: Concepts and cases. Long Range Planning.

22. Timmers, R. (1998). Business models for electronic market. Electronic Markets, Vol. 8, Iss. 2, pp. 3-8.

23. Witschel, D., and Dohla, A., and Kaiser, M., and Vogit, K., and Pfletschinger, T. (2019). Riding on the wave of digitization: insights how and under what settings dynamic capabilities facilitate digital-driven business model change. Journal of Business Economics, Vol. 89, pp. 1023-1095. 